\title{
Hawaii, Cannes, and Los Angeles: Projecting South Korean Cinema to the World
}

Sangjoon Lee*

In summer 2015, Star Wars: The Force Awakens dominated the box office in virtually every major film market on the planet. There were, however, two notable exceptions. Patrick Brezeski (The Hollywood Reporter) points out two markets where the force was not strong enough to hold local audiences - Vietnam and South Korea. At the South Korea box office, CJ Entertainment's mountaineering adventure drama The Himalayas (Himallaya, 2015) outperformed The Force Awakens. Vietnam's Star Wars-beating movie was, interestingly enough, Sweet 20 (Em là bà nội của anh), a remake of 2014 South Korean hit Miss Granny (Susanghan Kŭnyŏ). It was indeed a second regional remake. The Chinese version came first, only ten months earlier, with the title of 20 Once Again (Chóng făn èrshí suì, 2015). Surprisingly, all three versions were also produced (or co-produced) by CJ Entertainment, South Korea's media giant. Brezeski, thus, concluded his article with this line: "If there's any force to rival The Force, it might be just be the so-called "Hallyu, or Korean pop culture wave, which continues to dictate trends across much of Asia." 1

Certainly, South Korean cinema has been one of the most striking case

* Assistant Professor, Wee Kim Wee School of Communication and Information, Nanyang Technological University, Singapore.

1 Patrick Brezenski, "How Korean Pop Culture Beat 'Star Wars' in Two Asian Coun- 
studies of non-Western cinema success stories in the age of the neoliberal world order where Hollywood dominates the global movie consumer's mind, heart, and soul. Under the tsunami of the US products over the world's media marketplace, South Korean cinema has successfully defended itself. A little more than a decade ago, New York-based film magazine Film Comment had its first special issue on South Korean cinema - "Korean Prospects: Inside an Asian Cinema Powerhouse." Chuck Stephens, special issue editor, proclaims that South Korean cinema has undergone "one of the greatest renaissances in global filmmaking the world has ever seen." 2 As Stephens applauds, in 2001 South Korea became the first film industry in recent history to reclaim its domestic market back from Hollywood, and in 2006 local films had a 67\% market share, the highest such figures in the world, except America and India. Moreover, adding to this film industry success story, the high-quality South Korean local product flowed outward to global film markets to connect with international audiences both in commercial cinemas, art theatres, and at major international film festivals. Pak Ch'anuk (Park Chan-wook)'s Oldboy (Oltúboi, 2003) received the Grand Prix at the Cannes in 2003. Kim Kitŏk (Kim Ki-duk), on the other hand, had great success in Venice and Berlin with his idiosyncratic art-house cinematic works such as The Isle (Sŏm, 2000), 3-Iron (Pinjip, 2004), and, more recently, Pieta (P'iet'a, 2012). Other breakthrough auteurs, art-house and genre-bending specialists alike followed: Hong Sang-su, Lee Chang-dong, Im Sang-su, Kim Ji-un, Ryu Seung-wan, Bong Joon-ho, and Kim Dongwon.

The aim of this short survey essay is to rediscover and reevaluate a history of contemporary South Korean cinema, the ways in which South Korean cinema has been curated, exhibited, and received in the West

tries," The Hollywood Reporter, December 12, 2015, http://www.hollywoodreport er.com/news/star-wars-box-office-how-850450.

2 Chuck Stephens, "Local Heroes: The Many Faces of Korean Cinema's Perpetual Renaissance," Film Comment 40, no. 3 (November/December 2004): 36. 
through international film festival circuits, art houses, and specialized theatre chains in North America and, to some extent, Europe. This essay begins with the Hawaii International Film Festival (HIFF) in the early 1980s where South Korean cinema was 'discovered' by Anglophone film critics and academics for the first time and folds the discussion in the mid-2000s when South Korean cinema had finally become a fixture of the international film festivals after getting critical acclaims of celebrated auteurs.

\section{The Emergence of Korean Cinema Studies}

In the realm of the English-language academic circle, Korean cinema as a serious scholarly subject has been growing exponentially. Such scholars as Isolde Standish, David James, Rob Wilson, Kyung Hyun Kim, Paul Willemen, Seung Hyun Park, and Kathleen McHugh had initially ignited the field of Korean cinema studies ${ }^{3}$ and two monographs followed in the UK and US: Hyangjin Lee's Contemporary Korean Cinema:

3 Isolde Standish, "Korean Cinema and the New Realism: Text and Context," EastWest Film Journal 7, no. 2 (July 1993): 54-80; David E. James, "Im Kwon-Taek: Korean National Cinema and Buddhism," Film Quarterly 54, no. 3 (Spring 2001): 14-31; Rob Wilson, "Korean cinema on the road to globalization: tracking global/local dynamics, or why Im Kwon-Taek is not Ang Lee," Inter-Asian Cultural Studies 2, no. 2 (2001): 307-18; Kathleen A. McHugh, "South Korean Film Melodrama and the Question of National Cinema," Quarterly Review of Film and Video 18, no. 1 (2001): 1-14; Kyung Hyun Kim, "Male Crisis in New Korean Cinema: Reading the Early Films of Park Kwang-su," Positions: East Asian Cultures Critique 9, no. 2 (May 2001): 369-99; Kyung Hyun Kim, "Post-Trauma and Historical Remembrance in Recent South Korean Cinema: Reading Park Kwang-su's $A$ Single Spark (1995) and Chang Sŏn-u's A Petal (1996)," Cinema Journal 41, no. 4 (Summer 2002): 95-115; Paul Willemen, "Detouring Through Korean Cinema," Inter-Asian Cultural Studies 3, no. 2 (2002): 167-86; Seung Hyun Park, "Film Censorship and Political Legitimation in South Korea, 1987-1992," Cinema Journal 42, no. 1 (Autumn 2002): 120-38. 
Culture, Identity and Politics (2000) and Kyung Hyun Kim's The Remasculinization of Korean Cinema (2004). Since then, the field has witnessed a blossoming of Korean cinema studies both in the form of monographs and edited volumes. ${ }^{4}$ Steven Chung and Moonim Baek, accordingly, begin their introduction to a special issue for The Review of Korean Studies (2015) with this:

4 See David E. James and Kyung Hyun Kim, eds., Im Kwon-Taek: The Making of a Korean National Cinema (Detroit: Wayne State University, 2002); Julian Stringer and Chi-Yun Shin, eds., New Korean Cinema (New York: New York University Press, 2005); Frances Gateward, ed., Seoul Searching: Culture and Identity in Contemporary Korean Cinema (Albany: SUNY Press, 2007); Darcy Parquet, New Korean Cinema: Breaking the Waves (London: Wallflower Press, 2009); Jinhee Choi, The South Korean Film Renaissance (Middletown: Wesleyan University Press, 2010); Kelly Y. Jeong, Crisis of Gender and the Nation in Korean Literature and Cinema: Modernity Arrives Again (Lanham: Lexington Books, 2011); Brian Yecis and Aegyung Shim, Korea's Occupied Cinema, 1893-1948 (London and New York: Routledge, 2011); Hye Seung Chung, Kim Ki-duk (Urbana and Chicago: University of Illinois Press, 2012); Alison Pierse and Daniel Martin, eds., Korean Horror Cinema (Edinburgh: Edinburgh University Press, 2013); Steven Chung, Split Screen Korea: Shin Sang-Ok and Postwar Cinema (Minneapolis: University of Minnesota Press, 2014); Theodore Hughes, Literature and Film in Cold War South Korea: Freedom's Frontier (New York: Columbia University Press, 2014); Young-a Park, Unexpected Alliances: Independent Filmmakers, The State, and the Film Industry in Post-authoritarian South Korea (Stanford: Stanford University Press, 2015); Hye Seung Chung and David Scott Diffrient, Movie Migrations: Transnational Genre Flows and South Korean Cinema (Rutgers: Rutgers University Press, 2015); Brian Yecis and Aegyung Shim, The Changing Face of Korean Cinema: 1960 to 2015 (London and New York: Routledge, 2016); Steve Choe, Sovereign Violence: Ethics and South Korean Cinema in the New Millennium (Amsterdam: University of Amsterdam Press, 2016); Youngmin Choe, Tourist Distractions: Traveling and Feeling in Transnational Hallyu Cinema (Durham: Duke University Press, 2016); Dong Hoon Kim, Eclipsed Cinema: The Film Culture of Colonial Korea (Edinburgh: Edinburgh University Press, 2017); Jinsoo An, Parameters of Disavowal: Colonial Representation in South Korean Cinema (Oakland: University of California Press, 2018). 
As recently as the early 2000 s it was possible both to compile a comparatively short bibliography of publications on Korean cinema and to chart the central theoretical trajectories of research and writing on it... Even a casual search now will net dozens of monographs, collections, and special issues as well as hundreds of articles touching on myriad aspects of Korean cinema through a variety of methodological approaches that have grown out of the dispersed geographic and institutional forum in which Korean cinema studies has taken root. ${ }^{5}$

However, if we turn back our clock to the 1980 s - only four decades ago - South Korean cinema's place in the world was strikingly different. Film critics, journalists, cinephiles, universities, and museums, not to mention the international film festival circuits in the West had long been neglecting South Korean cinema, at least until the late 1980s. No major academic study of Korean cinema in English language could be found then. Most American research universities did not provide any courses devoted to South Korean cinema. South Korean cinema as a whole had been continuously marginalized and ghettoized no less than by Korean intellectuals themselves. Peter Doherty, in 1984, proclaims in his Asian Survey article: "No Korean film has yet established for itself an international reputation, and it is rare for a South Korean film to be screened at even the most esoteric film programs at universities or museum." In his opt-cited Third World Filmmaking and the West, Roy Armes, without hesitation, enunciates that "there are no internationally known film directors from South Korea."7 A renowned Japanese film scholar Markus Nornes

5 Steven Chung and Moonim Baek, "Guest Editors' Introduction: New Cartographies and Archaeologies of Korean Cinema," The Review of Korean Studies 18, no. 1 (June 2015): 7.

6 Thomas Doherty, "Creating a National Cinema: The South Korean Experience," Asian Survey 24, no. 8 (August 1984): 840-51.

7 Roy Armes, Third World Filmmaking and the West (Los Angeles and Berkeley: University of California Press, 1987), 156. 
reminisced about the late 1980s when he first encountered South Korean cinema during his graduate studies in Los Angeles. He stated:

The only book on Korean cinema was Lee Young-il and Choe Young-chol's overtly nationalist The History of Korean Cinema (1988). It left me thinking Korean cinema must be far more interesting than their book suggests. The only way to test this suspicion was to watch films, but this was not a straightforward matter. This was the tail end of the era when $35 \mathrm{~mm}$ movie theatres in Little Tokyo and Chinatown catered to their respective ethnic communities. I haunted those theatres weekly. However, Korean films posed a special challenge. Thankfully, USC bordered Koreatown, and I borrowed snowy VHS dubs from nearby grocery stores. ${ }^{8}$

South Korean cinema was, nevertheless, not the only non-western national cinema that had been "ignored" in Anglophone academic circles. Indeed, it was one of myriad 'invisible' non-Western national cinemas. Evoking the 1985 Asian Cinema symposium, organized by Wimal Disanayake in conjunction with the Hawaii International Film Festival, William Rothman wrote: "other than martial arts films, few of us had seen a single film from Hong Kong, Taiwan, or mainland China. And it goes without saying that the cinema of Korea, the Philippines, Indonesia, and Southeast Asia was completely unknown to us."9

Consider the case of the "now" prosperous field of Sinophone cinema studies, ${ }^{10}$ the subject was not considered important to many Chinese stud-

8 Markus Nornes, "Before the Wave: The Difference and Indifference of Hallyu Beta through 2.0," in Hallyu 2.0: The Korean Wave in the Age of Social Media, eds. Sangjoon Lee and Abe Markus Nornes (Ann Arbor: University of Michigan Press, 2015), 245-6.

9 William Rothman, "Overview: What is American about Film Study in America?" in Melodrama and Asian Cinema, ed. Wimal Dissanayake (Cambridge: Cambridge University Press, 1993), 255.

10 If I provide quantitative data for an overview of the market, the number of books 
ies specialists in the English-language academia, even in the 1970s. Chris Berry wrote: "Few people outside China had seen many Chinese films, and even fewer claimed to understand or like them...Within months all that changed when Yellow Earth (Huáng túdia, 1984) appeared at the Hong Kong Film Festival." 11 During the mid to late 1980s, it was Hong Kong International Film Festival where the so-called Fifth Generation directors had first been introduced to the outside world. ${ }^{12}$ Yellow Earth, after its Hong Kong screening, made its way to Locarno, Edinburgh, and Hawaii. Within a few years, major European festival programmers had competitively been searching for new East Asian film auteurs, particular-

on Chinese-language cinema and television, excluding literary-based textual analyses, single-author studies, and non-UK/US university publications, e.g. Hong Kong University Press, have multiplied, from the mere four single-volumes before 1990 to whopping seventy-plus books by the end of 2010. Among these impressive titles, almost thirty were introduced to the US/UK market between 2001 and 2005, with the help of, I believe, Ang Lee's Crouching Tiger, Hidden Dragon (2000) and Zhang Yimou's Hero (Yingxióng, 2002)'s tremendous success at the North American box office not to mention their worldwide phenomenon. During the period, the first comprehensive history book Chinese National Cinema, written by Yingjin Zhang, was published in 2004 as a new addition to Routledge's series on national cinema.

11 Chris Berry, "Introduction," in Perspectives on Chinese Cinema, ed. Chris Berry (London: BFI Publishing, 1991), 1.

12 According to Harry H. Kuoshu, film scholars commonly divided Chinese filmmakers into five generations; the pioneers in the 1920s (the first); the leftist filmmakers of the 1930s and 1940s (the second); the early PRC (People's Republic of China) cinema of the 1950s (the third); from the early 1960s to the post-Mao Late 1970s (the fourth); The Post-Mao cinematic new wave who has trained at the post-Mao Beijing Film Academy (the fifth); a group of young filmmakers who came out in the 1990s and are radically depart from the fifth generation filmmakers focusing on the contemporary Chinese youth culture and society (the sixth). Some of the most celebrated fifth generation film directors are Zhang Yimou, Chen Kaige, and Tien Zhuangzhuang. See Harry H. Kuoshu, Celluloid China: Cinematic Encounters with Culture and Society (Carbondale: Southern Illinois University Press, 2002), 2-3. 
ly emerging talents from China, Hong Kong, Taiwan, and to a lesser extent, South Korea. Zhang Yimou won the Silver Bear at the Berlin Film Festival with his feature debut Red Sorghum (Hóng gāoliángin) in 1987. Hou Hsiao-hsien has been a fixture on the international film festival circuit since his award at Venice in 1989 with City of Sadness (Bēiqing chéngshi). Edward Yang, Hou's peer, picked up a Silver Leopard at Locarno for The Terrorizer (Kǒngbù fènzì) in 1987. Together with Chen Kunhou, Hou and Yang would be known as leading figures of the Taiwan New Cinema (aka. New Taiwanese Cinema). And Kang Suyŏn (Kang Soo-yeon) received the Best Actress award at the Venice Festival in 1987 with Im Kwŏn-taek's The Surrogate Woman (Ssibaji).

Before long, a new cinema from South Korea, collectively grouped as "the Korean New Wave" emerged, ${ }^{13}$ in the same manner as the Western critics, journalists, and scholars have labeled "Hong Kong New Wave" in the late 1970s and "New Taiwan Cinema" in the mid-1980s. The Korean New Wave as a cinematic movement - still seeking for a clear definition and critical consensus among scholars - marked a rather belated arrival in this "treasure-hunting" game. It came after Hong Kong, China, and Taiwan, not to mention Japan's Shochiku New Wave several decades earlier. Indeed, South Korea became the last "uncharted territory" of East Asia for the international film festival circuits, particularly at Rotterdam, Berlin, Locarno, and Cannes. On the other side of the Atlantic Ocean, Hawaii International Film Festival (HIFF), launched in 1981, emerged to become

13 Korean film scholar Moon Je-cheol wrote: From the late 1980s, the so-called "Korean New Wave" began with figures like Park Kwang-su, Jang Sunwoo, and Lee Myung-se. The strategy of New Wave for implementing change was to combine auteurism with realism, thus creating a new approach to film they called auteurrealism. While the Western concept of auteurism emphasized film as art, auteurrealism in Korea operated as a practical strategy for challenging every facet of the Korean film institution." Moon Jae-cheol, "The Meaning of Newness in Korean Cinema: Korean New Wave and After," Korea Journal 46, no. 1 (Spring 2008): 39. Accordingly, I use the cinematic movement term "Korean New Wave" to referring to mid 1980s - mid 1990s directorial generation in South Korean cinema. 
a cultural contact zone for East and West on American soil. The Korean New Wave films had been introduced to critics and journalists, scholars, Asian cinema aficionados, and graduate students in America through HIFF. This film festival, and The East-West Film Journal, has paved the way for South Korean cinema toward the U.S. mainland that had long been marginalized in the standard film scholarship.

\section{The Korean New Wave and the Hawaii Film International Festival in the 1980s}

Certainly, the Hawaii International Film Festival (HIFF), established in 1981, and its mother institution The East-West Center (EWC) at the University of Hawai' $i$, was one of the most important venues not only for introducing Asian cinema to the American soil, but gathering young scholars and critics interested in the subject. EWC, established in Hawaii in 1960 by the US Congress, had initiated East-West Film Journal in 1986. Arguably the first American film journal devoted solely to the Asia-Pacific region as a whole, this short-lived film journal (last issue published in 1994) provided a forum in which Asian and Western cinemas could be introduced to and appreciated by a world-wide audience. Having been led by Wimal Dissanayake, John Charlot and Paul Clark, most articles included in the journal issues were based on conference presentations that EWC and HIFF had co-organized. Such (now) household names in the field of Asian cinema - Donald Richie, David Desser, Catherine Russell, Ma Ning, Keiko McDonald, Gina Marchetti, Chris Berry, Darrell William Davis, Yoshimoto Mitsuhiro, Krishna Sen, Markus Nornes, and Yingjin Zhang - and film critics like Tony Rayns, Roger Ebert, Kenneth Turan, and Jonathan Rosenbaum have contributed articles on Japanese, Taiwan, Hong Kong, Philippines, and Indian cinema. Most of them came from area studies or the field of comparative literature, and not many new Asian cinema scholars were trained in the approaches and methodologies of cinema studies. In contrast to cinema studies that 
had to be interdisciplinary and trans-regional by definition, area studies put more emphasis on linguistic competencies, cultural backgrounds, at least a few years' field research and a level of expertise in literary and critical theories. ${ }^{14}$ Differentiating themselves from the first generations of Asian film specialists - many of whom had to rely on translators - they were a new group of film scholars. The old tradition of film studies, wherein it was believed that appropriately "trained" cinema specialists could decipher and interpret any national cinema by using powerful "tools," has weakened since then. It is becoming more and more the field of "specialists" of the accumulated knowledge of a specific country.

Throughout the journal's lifetime - 8 years and 16 issues - East-West Film Journal published only three articles on South Korean cinema - one written by a South Korean film director Pae Ch'ang-ho (Bae Chang-Ho) who spent a year at EWC as a filmmaker-in-residence in $1987 .{ }^{15}$ Apparently, as discussed above, there was no specialist on the subject of South Korean cinema working in the English-language academia in the 1980s. Moreover, as Paul Willemen points out, "the difficulty of obtaining prints for study" "16 made South Korean cinema extremely marginal. Besides South Korean film critic Ahn Byong Sub's short essay, ${ }^{17}$ Isolde Standish's "Korean Cinema and the New Realism: Text and Context" should be considered one of the first scholarly works on South Korean cinema written outside the Korean peninsula. Standish particularly no-

14 Yoshimoto Mitsuhiro, "Questions of Japanese Cinema: Disciplinary Boundaries and the Invention of the Scholarly Object," in Learning Places: The Afterlives of Area Studies, eds. Masao Miyoshi and Harry D. Harootunian (Durham: Duke University Press, 2002), 368-401.

15 Chang-Ho Bae, "Seoul in Korean Cinema: A Brief Survey," East-West Film Journal 3, no. 1 (December 1988): 97-104.

16 Paul Willemen, "The Third Cinema Question," in New Latin American Cinema: Theory, Practices and Transcontinental Articulations, ed. Michael T. Martin (Detroit: Wayne State University, 1997), 235.

17 Byung-Sup Ahn, "Humor in Korean Cinema," East-West Film Journal 2, no. 1 (December 1987): 90-8. 
ticed the generation that some of South Korea's most prominent contemporary filmmakers have come from. "The Korean New Wave,"as she called it, "has come about as a 'revolt' against traditional conventions imposed by a stringent system of political censorship." She observed that the Korean New Wave dealt with new characters (the working classes, radical students), new settings (the factory, slum houses), and new problems (the north/south division, urbanization, industrial unrest, and family breakdown). Beginning in the late 1980s, HIFF introduced a new group of South Korean films, such as Pak Chongwŏn's Guro Arirang (Kuroarirang, 1989), Park Gwang-su's Chilsu and Mansu (Ch'ilsuwa Mansu, 1988), Sin Sŭngsu's Rooster (Sut'ak 1990) and Chang Sŏn-u (Jang Sunwoo)'s Love in Umukpaemi (Umukpaemiüi sarang, 1990; aka. A Short Love Affair). Even though the 1980s South Korean film industry was mainly dominated by soft-core erotica and comedies, those filmmaker's works "resist and modify" the dominant language and filmic conventions in South Korea. ${ }^{18}$ Many of "New Wave" Korean directors started their film career when they were engaged in "minjung cinema (minjung yŏnghwa)."

Minjung cinema movement did document, project, and represent the lives and relations of people that could rarely be found in the mainstream cinemas of Hollywood and Ch'ungmuro (the equivalent of Hollywood in South Korea). Labor union leaders, student activists, and the urban poor were given heroic representations in labor news produced by Labor News Group (Nodongja nyusŭdan), student films such as Blue Bird (P'arangsae, 1986), The Night Before the Strike (P'aópchŏnya, 1990), and independent documentaries including The Sangkye-dong Olympics (Sanggyedong Ollimp'ik, 1988). However, Minjung cinema movement soon lost its vitality largely due to the government's brutal suppression. Most of its filmmakers left the group and went to the Ch'ungmuro instead. Some achieved critical acclaims in South Korea and beyond.

18 Standish, "Korean Cinema and the New Realism," 68. 


\section{Dharma, Chilsu and Mansu, and A Petal}

"If recognition is the beginning of a history," Mitsuyo Wada-Marciano points out, "a history of Japanese film history literally started in 1951 outside of Japan, when Kurosawa Akira's Rashomon won first prize at the 1951 Venice Film Festival." 19 The West "discovered" the Japanese cinema, Robert Sklar claims, when Rashomon won the prize at the Venice. The Japanese cinema emerged as a major international force during this period. $^{20}$ Julian Stringer, in view of this, states that "non-Western cinemas do not count historically until they have been recognized by the apex of international media power, the centre of which is located, by implication, at Western film festivals." ${ }^{21}$ According to this logic, South Korean cinema was first "noticed" by the European film festivals in the early 1980s with Im Kwŏn-taek’s Mandala (1981) and Lee Du-yong's Mulleya Mulleya (Yöin janhoksa mulleya mulleya, 1984) were invited to the Un Certain Regard section of the 1984 Cannes Film Festival. But it was 1988-89 when Korean cinema was fully "discovered" with Pae Yongkyun (Bae Yongkyun)'s Why Has Bodhi-Dharma Left for the East? (Talmaga tongtchokŭro kan kkadalgŭn? 1989; Bodhi-Dharma hereafter), I Changho (Lee Jang-ho)'s The Man with Three Coffins (Nagŭnenŭn kiresŏdo shwiji annŭnda, 1988) that Amos Vogel claimed "the most original film" at the Berlin Film Festival in 1988, ${ }^{22}$ Park Gwang-su's critically acclaimed Chilsu and Mansu, and Im Kwŏn-taek's Come Come Come Upward (Aje aje para aje, 1989).

In 1989, Geoffrey Gilmore, before his tenure at Sundance Film Festival,

19 Mitsuyo Wada-Marciano, Nippon Modern: Japanese Cinema of the 1920s and 1930s (Hawaii: University of Hawaii Press, 2008), 1.

20 Robert Sklar, A World History of Film (New York: Harry N. Abrams Inc Publishers, 2002), 200.

21 Julian Stringer, "Global Cities and the International Film Festival Economy," in Cinema and the City, eds. Mark Shiel and Tony Fitzmaurice (Oxford and Malden: Blackwell Publishers, 2001), 135.

22 Amos Vogel, "Hallo," Film Comment 24, no. 3 (May/June 1998): 63. 
wrote that focus of attention on a South Korean director (in the West) "has never occurred" in the international art cinema circuit. ${ }^{23}$ But just a few months later, a relatively unknown newcomer Bae grabbed the Pardo d'Oro (Golden Leopard) trophy at the Locarno International Film Festival. Bodhi-Dharma had its initial European premier in the Un Certain Regard section at the 1989 Cannes International Film Festival then to the Locarno. It was one of the most talked-about films to receive a wide circulation among international film festivals in 1989. Although overshadowed by the unexpected triumph of Bodhi-Dharma, Chilsu and Mansu was named the winner of the Young Critic's Award at the same festival. Just a month ago, in July, South Korean actress Kang Suyŏn received the Best Actress award at the Moscow Film Festival with Come Come Come Upward. It was Kang's second Best Actress Award after the one at the Venice Festival in 1987. And, not long after, some fast-movers embarked on this frontier. Italians were the first. In 1992, the Pesaro International Film Festival in Italy organized a retrospective of South Korean cinema. Kim Chisŏk (Kim Ji-seok), Lee Yong-gwan, and Jay Jeon (Chŏn Yangchun) were invited to the screenings. ${ }^{24}$ In 1993, the Pompidou Centre in Paris and the New York Museum of Modern Art (MOMA) had mounted major retrospective of South Korean cinema. Tony Rayns was among the first critics who noticed South Korean cinema. In his introductory essay for Seoul Stirring: 5 Korean Directors (1994) that introduces Im Kwŏn-taek, Chang Sŏn-u, Park Gwang-su, Kim Ǔi-sŏk and I Myŏngse (Lee Myeongse) to the UK cinephiles, Rayns wrote:

It is hard to think of any national cinema that has been more innovative and surprising in the last five years than South Korea's. As in China, young generation directors marked by bad state poli-

23 Geoffrey Gilmore, "Window on Korea: New Korean Cinema," Koreana 3, no. 4 (Winter 1989): 22.

24 Davide Cazzaro and Darcy Paquet, "An Interview with Kim Ji-seok," Koreanfilm.org, October 12, 2005, http://koreanfilm.org/kimjiseok.html. 
tics have moved into the film industry, dissatisfied with the films they grew up with and determined to do different and better...their best work leaves most recent cinema from Western countries looking timid and under-nourished. ${ }^{25}$

Suddenly, South Korean cinema became "the next big thing" ${ }^{26}$ and "East Asia's best-kept secret." ${ }^{27}$ After winning Alfred Bauer Prize with a Buddhist-themed film Hwa-Om-Kyung (Hwaómgyŏng, 1993) at the $44^{\text {th }}$ Berlin Film Festival in 1994, British Film Institute (BFI) had commissioned Chang Sŏn-u to direct a South Korean entry in the BFI's "Century of Cinema" series of personal film essay to celebrate the centennial. The Cinema On the Road (Han'gukyŏnghwa ssitkim, 1995), with Tony Rayns' voiceover narration, had its world premiere at the $48^{\text {th }}$ Cannes Film Festival in 1995. Chang, much more prolific then, completed his criticallyacclaimed film, A Petal (Kkonnip, 1996), one year later, screened at Rotterdam Film Festival. Park Gwang-su also enjoyed his peak moment in his filmmaking career in the 1990s. Two film festival-favorite films - To

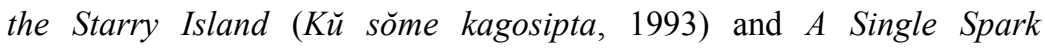
(Arŭmdaun ch ‘̆ngnyŏn Chŏn T'ae-il, 1995), had rave receptions at Three Continents Festival in Nantes, France, and the Berlinale respectively. As Kyung Hyun Kim points out, Park and Chang had gained "international reputations that afforded them prestige and respectability," to the extent that they were "capable of marketing themselves and their projects as auteurs." 28 For the first time in the history of South Korean cinema, Chang and Park were able to receive critical attention from the interna-

25 Tony Rayns, "Introduction," in Seoul Stirring: 5 Korean Directors - A Festival of Korean Cinema, ed. Simon Field (London: Institute of Contemporary Arts, 1994), 5.

26 Paul Harris, "It's Korean Film Making Waves Now," The Age, December 6, 1994, http://www.lexisnexis.com/hottopics/lnacademic.

27 Derek Elley, "The Cinema on the Road." Variety, June 26-July 9, 1995, 82.

28 Kyung Hyun Kim, "Post-Trauma and Historical Remembrance in Recent South Korean Cinema," 96. 
tional film festival circuits. But it was Im Kwŏn-taek who ended up garnering most acclaims from the Western film critics circle. Before long, Im had left his lasting clear signature on the map of world cinema.

\section{Pusan, USC, and Im Kwŏn-taek}

In September 1996, the first Pusan International Film Festival (now Busan) took place in the Korean port city. And just a month later, twelve of Im Kwŏn-taek's films were screened at University of Southern California (USC), presented by the School of Cinema-Television, Korean Studies Institute, the Korea Foundation, and the Korean Cultural Center in Los Angeles. ${ }^{29}$ This retrospective of Im and an accompanying academic conference, both organized by Kyung Hyun Kim and David James, was a critical breakthrough to the US reception of South Korean cinema. As David James recalled, the festival "culminated with Im's visit to Los Angeles and to the university, where he was presented with a lifetime achievement award by Arthur Hiller, then-President of the Academy of Motion Pictures." ${ }^{30}$ James and Kim, based on the conference's outcomes, edited a book Im Kwon-Taek: The Making of a Korean National Cinema (2002). Im then received an Award for Excellence in Filmmaking at HIFF in 1996 and the Kurosawa Award for Lifetime Achievement in Film Directing at San Francisco International Film Festival in 1998 - two film festivals that had served as primary venues for introducing South Korean cinema to America.

Together with Im's Chunhyang, "the trio of features"31 - Chang Sŏnu's Lies (Köjinmal, 1999) and I Myŏngse's Nowhere to Hide (Injŏng-

29 "USC fetes South Korean Helmer Im," Daily Variety, October 25, 1996, 30.

30 David E. James, "Preface," in Im Kwon-Taek: The Making of a Korean National Cinema, eds. David E. James and Kyung Hyun Kim (Detroit: Wayne State University, 2002), 9.

31 Stephens, "Local Heroes," 36. 
sajŏng pol kŏn ŏpta, 1999) opened in the US theatres in 2000. Nowhere to Hide was probably the most successful among American critics and cinephiles. Elvis Mitchell heralded the rave reviews accorded Nowhere to Hide at the Sundance screening. He wrote: "his (Lee) skills left the audience giddy and shaken from the kind of high you can only get in a dark room with several hundred strangers who feel exactly as you do." ${ }^{32}$ Jonathan Demme even cast Pak Chunghun (main protagonist of Nowhere) for his The Truth About Charlie (2002). None of the films mentioned above, disappointedly, had shown meaningful box office success in U.S. film market. But they clearly paved the way for more cinematic cutting edge filmmakers from South Korea to infiltrate the international arena.

However, Im's “big” international breakthrough came when Chunhyang (Ch'unhyangdyŏn, 2000) entered into the Cannes Film Festival's competition category in 2000. It was also the first South Korean film, premiering at the highly selective Telluride Film Festival. After Telluride, Chunhyang travelled to many festivals around the world, including HIFF (where it won the Best Narrative Award), Asia-Pacific, Pusan, Singapore, and New York Film Festivals. Im was even compared to "the late Akira Kurosawa" because "he (Im and/or Kurosawa) is the emperor, respected by everyone... his films bridge the gap between popular fare for the average Korean and art movies for students and cinephiles." 33 Im, two years later, became a winner of the Cannes Festival's Best Director award with his subsequent feature Chihwaseon (Ch'wihwasŏn; Fainted Fire) in 2002. Then Pak Ch'anuk, two years later, won the Grand Prix at the same festival with his cult classic Old Boy. Kim Kitŏk, Hong Sang-su, Lee Changdong, and Im Sang-su followed. The culmination was the massive South Korean film retrospective, entitled "60 Years of South Korean Cinema," being held at the Walter Reade Theater at Lincoln Center, New York, in

32 Elvis Mitchell, "Following the Films, Not the Cash, At Sundance," The New York Times, May 31, 2000.

33 Phillip Lopathe, "A Man for All Genres Who's Now Sui Generis," The New York Times, November 5, 2000. 
November-December 2004. With Im's Low Life (Haryuinsaeng, 2004) as an opening film, a total of 31 South Korean films were screened during the three-week schedule, including The Coachmen (Mabu, 1961), Why Has Bodhi-Dharma Left for the East?, Chilsu and Mansu, Peppermint Candy, and Aimless Bullet. And that year, Film Comment published a special issue on South Korean cinema.

\section{Conclusion}

Gavin Smith, editor of Film Comment, writes: "during the last 15 years, this tiger of Asian film culture has steadily transformed itself into a cinematic dynamo, generating ever more energy." 34 What Smith meant 'the last 15 years' originated the year of 1989 when the "world" discovered Bodhi-Dharma, Chilsu and Mansu, and Come Come Come Upward. For better or worse, South Korean cinema prior to 1989 has continuously been erased in the English-language film criticism and academic world. In a second edition of Wheeler Winston Dixon and Gwendolyn Audrey Foster's A Short History of Film (2013), the authors allocated a section, very brief one indeed, on South Korean cinema. They write: "modern Korean cinema is dominated by the figure of Im Kwŏn-taek, an incredibly prolific director with more than 100 films to his credit since 1962, although his works has received, as with so many other excellent Asian filmmakers, scant attention in the West outside of film festivals." 35 Other than Im, in their book, no South Korean director appears.

Accordingly, despite South Korean cinema's celebrated achievement in the global film market, its rich cinematic heritages, particularly the "golden age" of South Korean cinema, have not been treated properly hither-

34 Gavin Smith, “Editor's Letter," Film Comment 40, no. 6 (Nov/Dec 2004): 4.

35 Wheeler Winston Dixon and Gwendolyn Audrey Foster, A Short History of Film (New Brunswick: Rutgers University Press, 2013), 341-2. 
to. ${ }^{36}$ Although the field has recently greeted a number of major scholarly achievements that have extensively discussed Korea's cinematic legacies, it is still difficult to find scholarly articles on the pre-1990s South Korean films - almost none from the 1970s and 80s. And, furthermore, there was a dearth of papers on individual films and directors. Such auteurs like I Manhŭi (Lee Man-hui), Kim Kiyŏng, Yu Hyŏnmok, Han Hyŏngmo, Kim Su-yong, Ha Kilchong, I Changho, Pae Ch'angho, and many more directors whose cinematic treasures have not been written about in the Englishlanguage. Still, too many great films have not yet benefitted from insightful academic examinations. Even worse, the field has been waiting for a comprehensive history book but still no news yet. ${ }^{37}$ It is therefore Korean film researchers' responsibilities to discover, re-discover, re-evaluate, and re-write the history of Korean cinema.

36 Kathleen McHugh and Nancy Abelmann's edited volume South Korean Golden Age Melodrama is still the only scholarly work on this subject. McHugh and Abelmann periodize "the golden age" from 1955 to 1972. They wrote that during the period, "a number of South Korean directors produced a body of work as historically, aesthetically, and politically significant as that of other well-known national film movements such as Italian Neorealism, French New Wave, and New German Cinema." See McHugh and Abelmann, eds., South Korean Golden Age Melodrama (Detroit: Wayne State University Press, 2005), 2-3. More recently, Steven Chung's Split Screen Korea (2014) examines the 1950s and 60s Korean cinema (and North Korea in the 1980s) through the life and films of Shin Sang-Ok.

37 There is a high demand for Korean cinema studies. Not only teaching and research initiatives in North America and Europe, but also there is a new demand for teaching in Asia-Pacific academia. During the last few years, major universities in the region, particularly in Singapore, Hong Kong, South Korea, China, Japan, Australia, and New Zealand have established their competitive global programs eligible for foreign students coming from different countries all over the globe, and the programs have run courses on Asian Cinema, media, and popular culture as part of their curricula. Many of those universities began offering South Korean cinema and popular culture classes as regular modules and also for international summer programmes. Increasing number of instructors are using film texts to teach Korean history and society. 